\title{
A Review on Indian Women in Last Century
}

\author{
Md. Arif Anwar Hashami ${ }^{1 *}$, Ashok Kumar Sharma ${ }^{2}$
}

\section{ABSTRACT}

Women are one of the important entities of any society, but in India it has a status like a goddess since Vedic era but at the same time there was few difficulties in her life. The worst situation of women in this century in terms of crime index leads to break our myths about the goddess position of women. Position of women cannot be analyzed only with the myths or saying by the people. This article investigating position of women in terms of her status in Vedic era, Medieval period, British era and after Independence. Review investigating the position through psychology, Rights, health, education, FLFP and registered crime. This article tried to find out the exact position of women of last century.

Keywords: Indian Women, Health, Education, MMR, Rights, Notable Women

Indian women's specification itself makes them weak in terms of an organization as rural women or urban women, about middle class or lower class women, about Brahmin or scheduled caste women, about Hindu women or Muslim women. All these distinctions makes them weak through making division between them but it is her sign in the society by which she can be seen by the people like a person may be in favor of women who belongs to her community, So group and section also makes variation in her position. Status of woman is affected by many factors including economic development and political participation. With all different observations it was an ultimate question is the position of women was better in last century if yes than why if not then why not?

\section{Psychology about Women}

Ladies clothing blamed many time for being sexually harassed or raped since last few years while it is not true any way because victims of 7 year or 60 years. We cannot say, women are responsible for any kinds of oppression while dowry deaths provide one more proof that shows them as a soft target to make a victim. Consider the case of 1983 of Delhi where 690 young women died by Burning them. Thus we cannot say, myths glorify women or devalue them. Other

\footnotetext{
${ }^{1}$ Department of Sociology, Monad University, Hapur, UP., India

${ }^{2}$ Department of Sociology, Monad University, Hapur, UP., India

*Responding Author
}

Received: January 17, 2017; Revision Received: February 12, 2017; Accepted: February 15, 2017

(C) 2017 Hashami A, Sharma A; licensee IJIP. This is an Open Access Research distributed under the terms of the Creative Commons Attribution License (www.creativecommons.org/licenses/by/2.0), which permits unrestricted use, distribution, and reproduction in any Medium, provided the original work is properly cited. 


\section{A Review on Indian Women in Last Century}

problems faced by women were mistreatment due to the psychology of man. Mistreatment is a common to all women while she is at home or in office, it can be happened in roads also i.e. in terms of rapes, assaults and dowry-related murders. On the other hand when she is living at home, fear of violence, sex-selective abortions are other example of mistreatments.

\section{Problem statement}

Just after a little focus on glorious myths, beliefs and real problems, a natural question comes into the mind that what was the reality of past and present? Between all these pros and cons about the stories of old time and present situation motivates to know true picture and puts question discussed below:

Was the status of women better than status in year 2017? This is an open question to society because after year 200 we have saw the brutal rapes including well known Damini case of New Delhi in year 2013. What was the status of women in last century?

\section{HISTORICAL BACKGROUND}

As per the difference in status of women in India, where from the early time to today's India where Women is on the top since a very long time cannot assume easily. The status of women from unknown status in ancient times to the equal rights through medieval period has several phases been passed as summary in a nutshell:

\section{Ancient India}

Shobana and some other scholars believe that in ancient India, the ladies enjoyed equality as men in term of decisions of life including marriage however, some other hold contrasting view. As per some literature in early vedic period of women had right to choose her better half. According to some people women married at a mature age in regvedic time and had right to choose her husband. In that time's literature Rigveda, Upanishads, ladies were allowed to attend conferences and provides suggestions for example Gargi and Maitreyi. In that time some kingdom had wrong traditions also like nagarvadhu ('bride of the city'). Amrapali was the city that had such kind of traditions. Singh wrote in pre-Vedic period, the society in India was matriarchal so women occupied significant roles compared to men. Kumari et al assumed co education in schools known as Gurukulas on the behalf of Vedas. He assumed women as equal partners with equal prestige and status in that era. In that time presence of women were compulsory in every religious ritual. As per study of Gadhre, women had equal rights in early Vedic period while later (approximately $500 \mathrm{BC}$ ), this status began to decline. With the entry of Babur and Muhgal empire and later Christianity not provide a lot of freedom to women. With the starting of Jainism and Budhism there was some freedom provided to the ladies. After that time, with the rise of Sikhism Women has taken a lot of responsibility that has been provided them by the Gurus including Guru Nanak Dev. That told the ladies and gents both are equal in the sight of God. Shalini considered Indian society is patriarchal in character and found sphere of social life 


\section{A Review on Indian Women in Last Century}

heavily suppresses a woman whether she is a tribal woman or a Dalit woman, a factory worker or a clerk, a doctor or a university student; a Hindu, a Christian or a Muslim; a low caste or a high caste, a house wife, a prostitute or a religious, an educated one or an illiterate.

\section{The Medieval period}

As per hansa Mehta, The Indian women's position in the society further deteriorated during the medieval period. And after this period, Sati, child marriages and ban on widow remarriages became part of social life in India. With entry of Muslims, Indian women started to wear the purdah practice. Shobana written at that time due to the loss of war situation in the Rajasthan, among the Rajputs of Rajasthan, jauhar was started. In that time, Devadasis was in society that was elected through the competition were sexually exploited in some part of India. More than one marriage was allowed in that time especially in Hindu Kshatriya rulers. There was some example to marriage daughter in other community as a political marriage Jodha and Akbar Marriage was a famous example of this tradition. Zanana was in tradition in Muslim families. They had allowed deciding the money in terms of "Mehr" in the marriage. With these typical situations, few women succeeded in politics, literature, education and religion. Razia Sultana in that time was first woman "Sultana (Without any king)" have ever ruled Delhi. Mughal badshah Akbar defeated a queen Rani Durgavati who ruled ruled for fifteen years until her defeats By Akbar through Asaf khan in year 1564. Some other names also in fame like Chand Bivi, in 1590s, Jehangir's wife Nur jehan. In Hindu queens, Shivaji’s mother's Jijabai was famous due to her ability as a warrior and administrator.

The Bhakti cults questioned administrator and society for equality. Mirabai was a famous saintpoet in Bhakti movement for lord Krishna. Some other female saint-poets were Akkamadevi, Rami Janabai and Lal Ded. Bhakti sects within Hiduism such as the Mahanubhav, Varkari and many others were principle movements within the Hindu fold to openly advocate social justice. Jahanara Begum and Princess Zebunnissa known in hstory to influencing the ruling administration.

Shortly after the Bhakti movement, Guru Nanak, the first Guru of Sikhs also preached the message of equality between men and women. He advocated that women be allowed to lead religious assemblies; to perform and lead congregational hymn singing called kirtan or Bhajan; become members of religious management committees; to lead armies on the battlefield; have equality in marriage, and equality in Amrit (Baptism). Other sikh Gurus also preached against the discrimination against women.

\section{Historical practices}

Shobana written about traditions in detail as, tradition such as sati, jauhar, child marriage, and devadasi have been banned and are largly defunct. However, some cases of these practices are still found $n$ remote parts of India. The pardah is still practiced by many Indian women. 


\section{A Review on Indian Women in Last Century}

\section{British Rule}

Some queens were known for fight against the English rulers including Rani Laxmi Bai, the queen of Jhansi, fought against them in Rebellion of 1857. Begum Hazrat mahal from Awadh tried to fight with Britishers in 1857 after refusal of deal with the British rulers and later retreated to Nepal. These Begums and queens did not observe purdah or other practice and were trained in martial arts.

Britishers observed in $19^{\text {th }}$ century that the Hindu women are in trouble with name of different traditions. Some reformers such as Ram Mohan Roy, Ishwar Chandra Vidyasagar, Jyotirao Phule etc. fought for the better future of women. Raja Rammohan Roy's tried to remove Sati practice in 1829 and found success. Ishwar Chandra Vidyasagar's tried to make a better life for widows through the remarriage and got success to pass the widow Remarriage act 1856 bill. A delegation in 1917, demanded to British Secretary of states for women support in political rights under the banner of Indian National Congress. Child marriage was common in early years of last Century then according to literature cited by haider et al [16], In 1929, the Child Marriage Restraint Act established to set minimum age of marriage as 16 for girls and 18 years for boys. Courts were also empowered to issue an injunction against such a marriage. In 1939, the Dissolution of Muslim Marriages Act sought to grant women the right to improve their status and to obtain judicial relief. Few Women played an important part in India's independence struggle including the name of Bhikaji Cama, Dr. Annie Besant, Pritilata Waddedar, Vijayalakshmi Pandit, Rajkumari Amrit Kaur, Anjali Ammal, Aruna Asraf ali, Sucheta Kriolani, Kasturba Gandhi, Muthulakshmi Reddy and Durgabai Deshmukh etc. The Rani of jhansi regiment of Indian National Army consisted entire woman force led by Captain Lakshmi Sahegal under guidance Subhash Chandra Bose's. Sarojini Naidu was a poet, freedom fighter, was the first Indian woman to become the President of the Indian National Congress and the first woman to become the governor of a state in India. Chandramukhi Basu, Kadambini Ganguly and Anandy Gopal Joshi were taken educational degrees in that period.

\section{Independent India}

After Independence, women are now participating in all activities such as education, politics, media, art and culture, service sectors, science and technology, etc.

Kumar says in his article, The Constitution of India guarantees to all Indian women equality (Article 14), no discrimination by the State( Article 15(I)), equality of opportunity (Article 16), equal pay for equal work (Article 39(d)).In addition it allows special provisions to be made by the state in favour of women and children (Article 15(3)), renounces practices derogatory to the dignity of women (Article 51(A) (e)), and also allows for provisions to be made by the State for securing just and humane conditions of work and for maternity relief. (Article42). According to kumar, feminist activism picked up momentum during later 1970s after a rape issue was in light from Mathura where women's group comes together. After this issue different Female activists 


\section{A Review on Indian Women in Last Century}

united on issues such as female infanticide, gender bias, women health, and female literacy. Kumar thinking alcoholism is often associated with violence against women; many women group launched anti-liquor campaigns in Andhra Pradesh, Himanchal Pradesh, Haryana, Orissa, Madhya Pradesh and other states. Many Indian Muslim women have questioned the fundamental leaders' interpretation of women's rights under the Shariat law and have criticized the triple talaq system. According to Kumar, in 1990s, grants from foreign donor agencies enabled the formation of new women-oriented NGOs. Self-help group and NGOs such as self Employed Women's Association (SEWA) have played a major role in women's right in India. Many women have emerged as leaders of local movements. For example, Medha Patkar of Narmada Bachao Andolan. 2001 was considered as a year of Women's Empowerment (Swashakti) by the government of India after passing policy for the Empowerment of Women. Kirmani and nida discusses the case of 2005 about a Muslim rape victim, Imrana who was highlighted in the media. Imrana was raped by her father-in-law and in result under an order by some Muslim clerics she is going to marry with her father-in-law. In this case her father-in-law was given a prison term of 10 years, verdict was welcomed by many women's group and the All India Muslim Personal Law Board.

Shilini, Social life for the majority of Indian women is confined within the four walls of the family. Once they are married most of them are isolated and are allowed to have no more social contacts. Here, family is never considered as a villain, Saju beliefs family as the basic unit of a society, and made up by the combination of a good understanding pair of a male and female who has socially or religiously accepted rites to living with each other. Sometimes, few activists also beliefs that man dominating family structure based on the patriarchal system with dominating nature is responsible for the degradation of women. Women are supposed to have no identity of their own apart from their ties to their husbands. They cannot assert themselves in any situation. They are known only in terms of their relation with the male members of their family. A woman's status is considered always in relation to a male: either the daughter of her father, or the wife of her husband or the mother of her son. For an Indian woman no identification without husband, brother and father is accepted in the society. Man considered the household work as the most shameful for a man while he assumes her wife to do it. So Indian women tried to do it and she resides in home to perform it in better way. With these situations Indian girls assumes her as a inborn able to household job after being a housewife and assume herself to be a better half for a men as so called "ardhangini". But in this case only wife-beating is a socially tolerated crime among the illiterate poor ladies especially in villages.

\section{WOMEN'S RIGHT}

The term Women's rights refers to the freedoms inherently possessed by women and girls of all ages, which may be institutionalized, ignored or suppressed by law, custom, and behavior in a particular society. Issues commonly associated with notions of women's rights include, though are not limited to, the right: to bodily integrity and autonomy; to vote (universal suffrage); to 


\section{A Review on Indian Women in Last Century}

hold public office; to work; to fair wages or equal pay; to own property; to education; to serve in the military or be conscripted; to enter into legal contracts; and to have marital, parental and religious rights.

\section{Historical background}

As per I.R.Jangharia, In the Middle Ages, an early effort to improve the status of woman occurred during the early reforms under Islam, when women were given greater rights in marriage, divorce and inheritance. Women were not accorded with such legal status in other cultures, including the West, until centuries later. Dr Ali Al-Tarafi says that the general improvement of the status of Arab women included prohibition of female infanticide and recognizing women's full personhood. Khorshid and Googleberg wrote in his books in his compiled book as "The dowry, previously regarded as a bride-price paid to the father, became a nuptial gift retained by the wife as part of her personal property". Under Islamic law, marriage was no longer viewed as a "Status" but rather as a "contract”, in which the woman's consent was imperative. "Women were given inheritance rights in a patriarchal society that had previously restricted inheritance to male relatives.

\section{Reproductive Rights}

As per the NHRI, Idea of Human rights discussed by United States, in International Conference, in 1968, “A Reproductive rights are rights relating to sexual reproduction and reproductive health.” The sixteenth article of the proclamation of Teheran states, "Parents have a basic human right to determine freely and responsibly the number and the spacing of their children." Since then, reproductive rights have been established as human rights in international human rights documents.

\section{Right in Inheritance}

Indian society generally not provides so many rights on property in her own home after her marriage. Society provides some rights but according to persons of different mindset these are very limited and frequently violated. In the mid-1950 the Hindu personal laws adopted to be applied on all Hindus, Buddhists, Sikhs and Jains to apply ban on rude practices including polygamy and giving rights to women for inheritance, adoption and divorce. On the other hand Muslim personal laws allow polygamy and much differs from that of the Hindus. Initially, according to Hindu Laws sons had a natural right on share on the ancestral property; however, daughter's shares is limited till the marriage and she received by their father but after few amendment now by laws daughters have equal rights on properties naturally.

\section{Land and Property Rights}

In early days, women do not have registration of property in their own names, and not had share of parental property. Due to weak law in her favor, women had little access to land, house and property. The Hindu personal laws provided a right to inheritance of women belongs to Hindus, 


\section{A Review on Indian Women in Last Century}

Buddhists, Sikhs and Jains from mid 1956. A case of year 1986, in which the Supreme Court of India given a decision in favor of a Muslim lady Shah Bano who was an old divorced Muslim woman as making her eligible for maintenance money. However, this rule was strongly opposed by Muslim leaders with the argument that the court is interfering in their personal law. The Government of India passed the Muslim Women's (Protection of Rights Upon Divorce) Act. The Christian women had also struggled over years for equal rights of divorces and succession. In year 1994 churches made tried to short out problems of women jointly with the women's organizations, and drew up a draft law known as The Christian Marriage and Matrimonial Causes Bill.

\section{Reservation}

As per Indian Constitution, any women having the right to get job for that a male is eligible if she can but after seeing not a lot improvement by this law in women empowerment the government started reservation for women in nearly every job except few illogical for women like Forces. In this row, Government reserved the seat of Head (Pradhan) in Indian Panchayat Raj Institutions. In Panchayati Raj Institution approximate 1 million women had actively entered in rural level politics. Government reserved $33 \%$ of seats in local bodies through the $73^{\text {rd }}$ and $74^{\text {th }}$ Constitutional Amendment Acts by which they were included in local government of nearly 500,000 villages. Since, the onset of PRI, the percentages of women has been increased from 4$5 \%$ to $25-40 \%$.

\section{Equality given by religion for women}

According to literature, powerlessness is another problem that provides gender biasness. In the presence of clear laws under constitution with guaranteed equality legal protection has little effect in the face of prevailing patriarchal traditions. Women lack power to decide who they will marry, and are often married off as children. To provide surety of equal status for women practically not theoretically, only the Gurus made no distinction between the sexes in matters of instruction or participation in the sangat, holy fellowship, and Pangat. According to some Gurus and dignitaries Sarup Das Bhalla, Mahima Prakash, Guru Amar Das disfavored the use of veil by women. He assigned women responsible for supervising the communities in certain sectors, and preached against the custom of sati. In Sikh history several ladies such as Mai Bhago, Mata Sundari, Rani Sahib Kaur, Rani Sada Kaur and Maharani Jind Kaur played a leading role evently.

\section{Praised treatment of enemy women}

Sikh was highly religious people to behave according to the order given by their Gurus, they treats the enemy women in praised way. In early day of wars when they were in several fights with Mudhals, there was an incident to behave women in praised way. In the days of trial and suffering, Sikhs were guided to give respect to the women folk of enemy captured in battle. In 1763, one of Ahmad Shah Durrani's generals, Jahan Khan, was defeated by the Sikhs at Sialkot 


\section{A Review on Indian Women in Last Century}

and his female dependants caught. Ali ud-Din writes in his Ibratnamah, "as the Sikhs of old would not lay their hands on women. They had them escorted safely to Jammu." They showed towards them utmost respect. Sikh made the rule to respect the womanhood, polygamy a rare exception. Female infanticide is prohibited. The codes of conduct discussed in the Rahitnamas, prohibit Sikhs from having any contact or relationship with those who indulge in this practice. As for sati widow-burning, Scripture itself rejects it.

As per sardar Harheet singh, in the Sikh system, they are the equals for men in all respects. They can lead congregational services and participate in akhand paths, uninterrupted readings of scripture to be accomplished within forty-eight hours. They vote with men periodically to elect Sikhs' central religious body, the Shiromani Gurdwara Parbandhak Committee, which administers their places of worship. Valarei Kaur wrote on Equality of Women, in Sikh Ideology and Practice as A drastic distinction between the roles of the male and female exists in all of history's modern human societies. Women have grown to accept, not without resentment though, the male-dominated atmosphere of the world. Because people use religious doctrine to define their life styles, religious scriptures in both the East and the West seem to condone, even encourage, the unequal treatment of women. In the 15th century, Guru Nanak established Sikhism, the first religion to a6ocate emphatically the equality. In a continent characterized by severe degradation of women, this bold declaration, along with others, determined to erase the impurities of the Indian society. However, prejudices and injustices based on gender linger even today.

As per Valarei, at the time of Guru Nanak, Indian women were severely degraded and oppressed by their society. Given no education or freedom to make decisions, their presence in religious, political, social, cultural, and economic affairs was virtually non-existent. Woman was referred to as "man's shoe, the root of all evil, a snare, and a temptress." Her function was only to perpetuate the race, do household work, and serve the male members of society. Female infanticide was common and the practice of sati, the immolation of the wife on her husband's funeral byre, was encouraged, and sometimes even forced. Guru Nanak condemned this manmade notion of the inferiority of women, and protested.

\section{NOTABLE WOMEN}

A lot of women make up carrier in different areas and got fame in his particular area some of the most famous name included here as:

\section{Sectors with Notable Women}

Arts and Entertainment: Singers and vocalists such as M.S. Subbulakshmi, Lata Mangeshkar, Asha Bhosle, Many actresses such as Aishwarya rai, Karina kapoor are highly popular. Anjolie Ela Menon is a famous painter, saroj dhingra is the biggest nautankibaaz. 


\section{A Review on Indian Women in Last Century}

Sports: Although the general sports scenario in India is not very good, some Indian women have made notable achievements in the field. Some of the famous female sportspersons in Indian include P.T. Usha (athletics), Kunjarani Devi (weightlifting), Diana Edulji (cricket), Koneru Hampi (chess) and Sania Mirza (tennis). Karnam Malleswari (weightlifter), Fogat sisters (Kushti), Marry Com and several more are Indian woman to have won Olympic medals.

Politics: Through the Panchayat Raj, over a million women have actively started her political life. As per the $73^{\text {rd }}$ and $74^{\text {th }}$ Constitutional Amendment Acts, women have reserved one-third seat in local body while the percentage of women at various level in political activity have improved, women are in governance and decision making positions. Woman's Reservation Bill passed in Parliament for her reservation in central and State Assembly. Some of the notable women leaders in India include Sushma Swaraj, Vasundhara Raje Scindia, Sheila Dixit, Mehbooba mufti, Uma Bharti, Mayawati, Mamata Banerjee, Meera Kumar, Sumitra Mahajan and Sonia Gandhi.

Literature: Anita Desai, Arundhati Roy, Shashi Deshpande, Shobha De, Kiran Desai, Sarojini Naidu were notable names as a reputed Indian authors.

Other Fields: Tarla Dalal is a popular cookery author, who has written more than 30 books. Several of her books have been translated into various languages, and the total sales of her books exceed 1 million copies. Shahnaz Husain is one of the most popular Indian beauticians and entrepreneur while Ritu Berry is a notable fashion designer.

\section{Defining feminism in the Indian context}

Women's issues in India are different from the western world due to here historic circumstances and society. Always two kind of systems considered one is patriarchal while second is matriarchal. In India, both systems have its importance but patriarchal culture is more powerful than second in general while first is in use in the south Indian region. It is visible fact in all the sections that patriarchal culture used and followed by people in society so rule and traditions are made under his favor. Indian ladies survives throughout her life with a patriarchal family structures in a queue of different practices like ordinal status, in conjunction with a men after marriage and other patriarchal attributes including dowry, caste, community, village and language. It is also equally true that several communities in India including Nairs of Kerela, some Maratha and Bengali clans are commanding by oldest women rather than the oldest man. Some north Indian communities including Sikh also regarded as relatively gender-neutral. India is a country with heterogeneity in terms of multiple patriarchies and multiple feminisms. So we can say Indian feminism is not a straight forward theory but is has liberty to be changed over time as well as changes in cultural realities of women and women as group. 


\section{A Review on Indian Women in Last Century}

In western world an individual single lady has rights and not seen with different eyes while in India living single was tough job in society for women. Indian women fought with society and struggle a lot to carve her identity as an independent individual. They define feminism without copying western value blindly. The widely used definition is “An awareness of women's oppression and exploitation in society, at work and within the family, and conscious action by women and men to change this situation”

\section{POSITION OF WOMEN}

\section{In Labor force participation}

To analyze the position of women in last centuries, we have chosen data from few reports and research papers, in this row, we have chosen data of few sectors including result of Jain(1996) shown in working paper by SOFA team \& Cheryl Doss [36] to find out Women labor force participation in agriculture sector within all Asia region. In which graph it had been shown the average women participation was 32 \% while Rajasthan was on top and West Bangal was on bottom. Here this is considerable that china had more women workforce participation from participation than maximum workforce participation having state of India and more than average of Indian Women participation in average also.

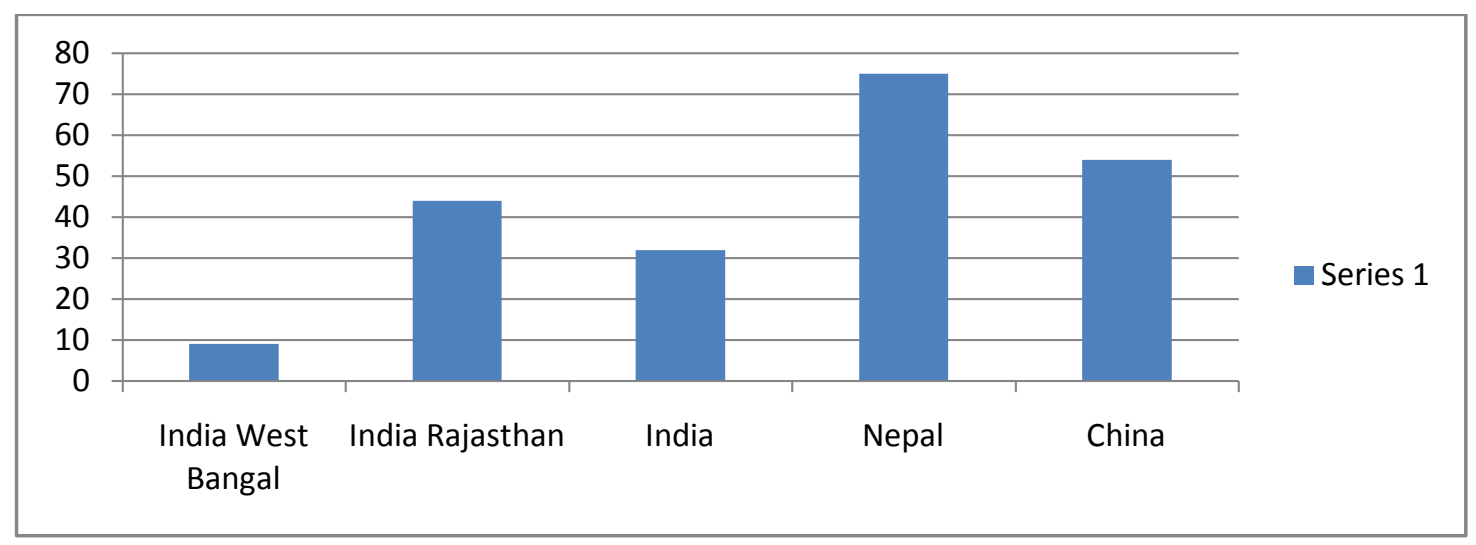

Figure 1: Proportion of labor in all Agricultural activities that is supplied by women

\section{Employment status}

Overwork was a big problem for the working women; they were handled home with the job. Women work hard even she is at home they do 24 hours job of childcare in most of the homes. In case of working women they tried to do double duties. Table provides total usually employed workers of year 1993-1994 and 1999-2000 from rural area and urban area respectively as per survey.

Table 1: Number of persons employed per 1000 persons according to usual status

\begin{tabular}{|c|c|c|c|c|}
\hline year & \multicolumn{3}{|c|}{ Usually Employed } \\
\hline & Male & Female & Male & Female \\
\hline & 531 & 299 & 518 & 139 \\
\hline $\mathbf{1 9 9 9 - 2 0 0 0}$ & 553 & 328 & 521 & 155 \\
\hline
\end{tabular}

(c) The International Journal of Indian Psychology, ISSN 2348-5396 (e) | ISSN: 2349-3429 (p) | 172 


\section{A Review on Indian Women in Last Century}

\section{Education}

As pr Kumar and Sangita literacy rate was increasing. In last century, family were far likely to be interested to highly educate girls than boys, and far more likely to pull them out of school, either to help out at home or from fear of violence.

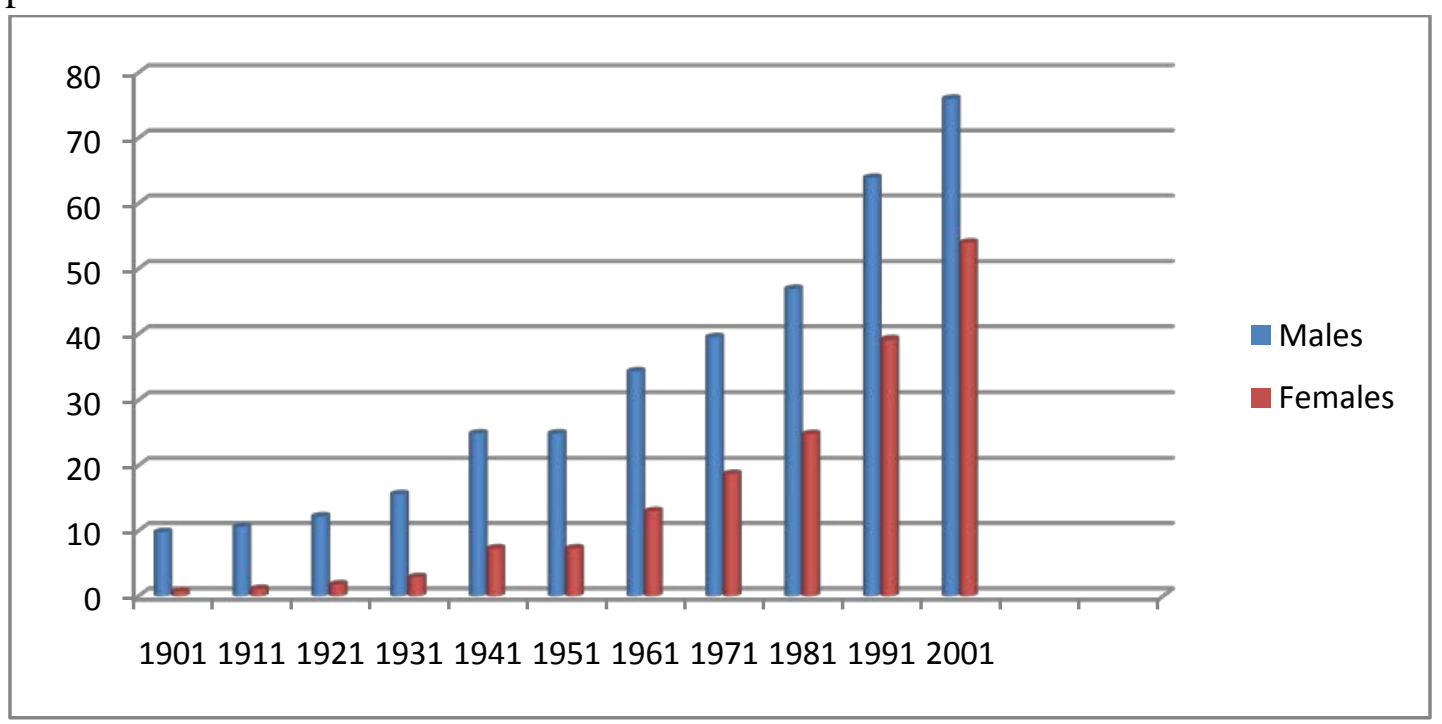

Figure 2: Literacy rate of India from 1901-2001

\section{Health}

Indian women have problems including malnutrition, poor health and high MMR. In India, as per the tradition women eat last and least throughout their lives, even when pregnant and lactating. Malnourished women give birth to malnourished children, perpetuating the cycle. They have poor health due to mostly living at home and less proper checkups or other reasons have less health care than males. Many women die in childbirth that might be safe if healthcare can provide them on time. So MMR is going high. India is the country which has maternal mortality rates in rural areas are highest in the world. As per Chatterjee (1990) estimation deaths of young girls in India exceed those of young boys by over 300,000 each year, and every sixth infant death is specifically due to gender discrimination. Dr. Sangmitra and Dr. Bacchan Kumar assumed India's total fertility rate of 3.8 births per women can be considered moderate by world standards. Overall India's health status was not good as per seen in figure given below:

(c) The International Journal of Indian Psychology, ISSN 2348-5396 (e)| ISSN: 2349-3429 (p) | 173 


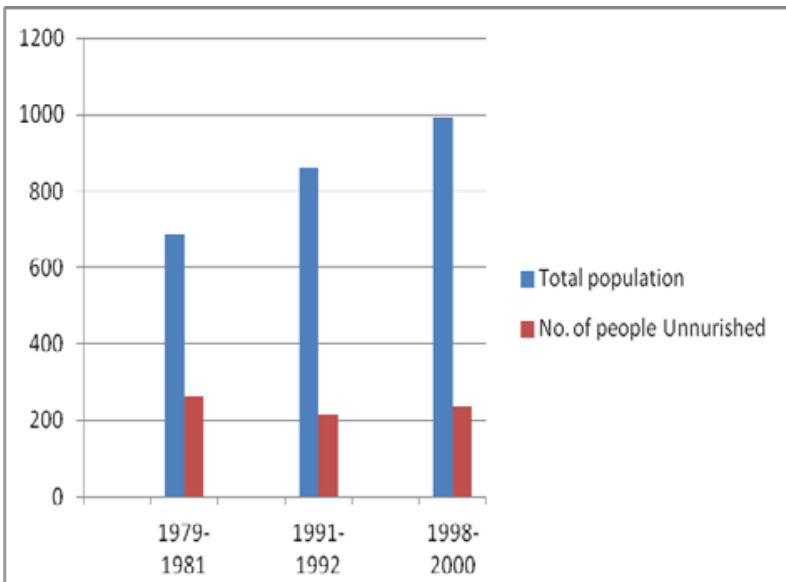

Figure 3: Unnourished Population

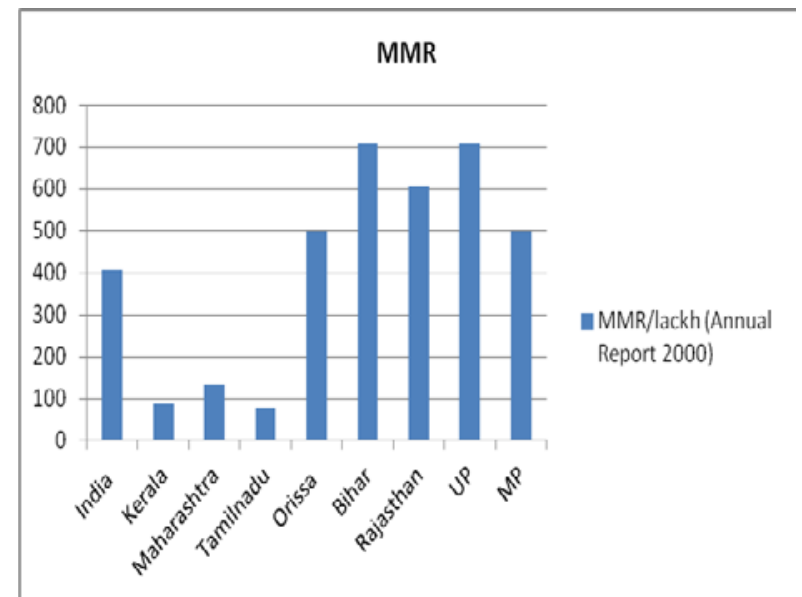

Figure 4: MMR of big states of India

\section{Political Status}

In Independent India Women were situated on most of the strong political places including Governer, Chief Minister and Prime Minister also but reason for placement only were few including strong family background, strong cast vote background, and strong financial status with the education in general cases. A politically strong woman generally comes from political families or from strong financial families of upper casts section in India. Smt. Indira Gandhi as a prime minister, Smt. Sucheta Kriplani, Smt. Shashikala Kakodkar, Smt.Syeda Anwara Taimur, Smt. Janaki Ramachandran, Smt. Jayalalithaa, Smt. Rajinder Kaur Bhattal, Smt.Rabri Devi, Smt. Sushma Swaraj, and Smt.Mayavati as achief minister, Meira Kumar as a Parliament member, Smt. Sonia Gandhi as a leader of opposition coming from different sections of upper cast and scheduled cast were the example of their strong family background or strong cast vote.

\section{CONCLUSION}

Statuses of women were coming strong from the Independence of India with the help of few human rights and women empowerment policies of Indian Governments. Only the crime against women is the factor that is growing after independence and generally due to the cause of psychology of people. Other factors of women's problem were high MMR, poor health, malnutrition, Powerlessness, less employment and patriarchal trends that providing male oriented psychology of men. While all these problems were directly correlated each other as with the patriarchal psychology society not provided them equal rights everywhere so they were in general less educated and employed that is why they were weak financially. This financially and politically weakness gives them a poor health, malnutrition and high MMR.

\section{Acknowledgments}

The author appreciates all those who participated in the study and helped to facilitate the research process. 


\section{A Review on Indian Women in Last Century}

Conflict of Interests: The author declared no conflict of interests.

\section{REFERENCES}

Aly Khorshid, “Euromoney encyclopedia of Islamic finance’, Euromoney Books, 2009

Avinash Gadhre, The Socio-Economic Status of Women in India Ancient to Modern Era,http://www.legalservicesindia.com/article/print.php?art_id=1867 on 19/06/2015.

Dr Ali Al-Tarafi, “You Think You Know Islam?”, Xlibris, 2016.

Dr. Jitendra Kumar \& Ms. Sangeeta, Status of Women Education in India, Educationia Confab, Vol. 2, No. 4, April 2013 162, ISSN: 2320-009X.

Dr. Sangmitra and bacchan kumar, "Encyclopedia of Women South Asia", Volume 1, Kalpaz publication, Delhi, 2004.

Dr. shobana Nelesko, "Status of women in India”, Deep \& Deep publication pvt. Ltd. New Delhi.

Employment and Unemployment Situation in India: 1999-2000, NSS 55th ROUND, Report No. 458(55/ 10/2), May 2001.

Haider, Nadya (2000) "Islamic Legal Reform: The Case of Pakistan and Family Law," Yale Journal of Law \& Feminism: Vol. 12: Iss. 2, Article 5, 2000.

Hansa Mehta; Indian Woman, op.cit., p. 95.

I.R.Jangharia, An alternative decision: “... you certainly owe it to yourself.”, Authorhouse UK Ltd, 2010.

Kumari, Women in Politics: Participation and Governance, 21. All sacred rituals are to be "Sapatnika" (with wife), otherwise these rituals are useless. Scholars like Asthana and Majumdar accepted her role in society as the measuring rod in assessing the standard of culture. See also, Pratima Asthana, Women's Movement in India (Delhi: Vikas Publishers, 1974), 150; Dhirendra Nath Majumdar, Races and Cultures in India (Bombay: Asia Publishing House, 1961), 104; Rani Moses, "Empowering Women," in Dalit and Women: Quest for Humanity, ed. V. Devasahayam (Madras: Gurukul, 1992), 195.

Meenakshi Sharma and Meena Shukla, "Role of Government in Women Empowerment: Myth and Reality," in Women Empowerment: Today's Vision for Tomorrow's Mission, ed. Meenu Agrawal (New Delhi: Mahamaya Publishing House, 2007), 166

Merline areeparampil sh , lambert leijssen, “ a relevant theology of women empowerment in the contemporary catholic church and society in india with special reference to mulieris dignitatem", faculty of theology, katholieke universiteit leuven, a thesis, 2009.

Reproductive rights are human rights: A handbook for national human rights institutions, NHRI.

Saju Chackalackal, "Planning a Family in the Context of Gender Discrimination," Journal of Dharma 29 (2004): 249.

Sanjay Kumar, WOMEN EMPOWERMENT, Volume 3, Issue 3, International Journal of Research in Economics \& Social Sciences, (April 2013) ISSN: 2249-7382.

Saraswathy Govindarajan, "Caste, Women and Violence," in Daliths and Women, ed. V. Devasahayam (Madras: Gurukul Lutheran Theological College and Research, 1992), 154. 


\section{A Review on Indian Women in Last Century}

Sardar Harjeet Singh, Faith and philosophy of Sikhism, Gyan publishing house, 2009.

Shalini, "Liberation of Women Some Indian Issues," 810.

Shalini, "Liberation of Women Some Indian Issues," Vidyajyoti 61 (1997): 809.

Shefali tiwari, Ruchita Shandilya, Media efforts flushed by Sunken Judiciary: Damini case Juvenile Verdict, Volume 6, issue 5, Pacific Business Review International, November 2013.

Singh, "Empowerment of Women in Urban Administration," 124. Women are rather considered indispensable for certain rites as men cannot be a spiritual whole without her participation.

Valarie Kaur, Abstracts on Sikh studies, Institute of Sikh studies, 2002.

Versha kumari, seemia mohanti, "problems and challenges faced by urban working women in India”, NIT, Rourkela, 2014.

How to cite this article: Hashami A, Sharma A (2017), A Review on Indian Women in Last Century, International Journal of Indian Psychology, Volume 4, Issue 2, No. 89, ISSN:23485396 (e), ISSN:2349-3429 (p), DIP:18.01.096/20170402, ISBN:978-1-365-74162-3 